Volume 1 Issue 2 (2017) Pages 86 - 96

Jurnal Obsesi : Jurnal Pendidikan Anak Usia Dini

DOI: $10.31004 /$ obsesi.v1i2.19

Jurnal Obsesi

\title{
Pengembangan Model Pembelajaran dengan Permainan Tradisional Engklek Sebagai Sarana Stimulasi Perkembangan Anak Usia Dini
}

\author{
Hidayatu Munawaroh ${ }^{\bowtie}$ \\ Universitas Sains Al-Qur'an, Wonosobo, Jawa Tengah
}

\begin{abstract}
Abstrak
Penelitian ini bertujuan untuk Mengetahui Model Pembelajaran dengan Permainan Tradisional Englek Sebagai Sarana Stimulasi Perkembangan Anak Usia Dini di RA Masythoh Singkir Wonosobo, Mengetahui Pelaksanaan Model Pembelajaran dengan Permainan Tradisional Engglek Sebagai Sarana Stimulasi Perkembangan Anak Usia Dini. Jenis penelitian adalah Penelitian Pengembangan (Research and Development). Subjek penelitian adalah anak kelompok B di RA Masythoh singkir Wonosobo. Metode pengumpulan data penelitian menggunakan: Observasi, Wawancara dan Dokumentasi. Hasil penelitian menunjukkan: (1) Model pembelajaran permainan engklek diantarkan melalui cerita dengan bantuan poster,menyanyi bersama,tanya jawab, menebak gambar dan bermain puzzle pada tema macam-macam profesi. (2) Pelaksanaan Model Pembelajaran Permainan engklek yang dapat menstimulasi aspek perkembangan Anak Kelompok B di RA Masythoh Singkir Wonosobo dilakukan sebanyak dua kali pertemuan, sesuai dengan $\mathrm{RKH}$, hasil rata-rata skor indikataor aspek perkembangan anak mengalami peningkatan aspek perkembangan anak. (3) Keefektifan model pembelajaran menggunakan permainan engklek efektif. Hal ini didukung oleh hasil perhitungan t tes. Simpulan penelitian ini adalah model pembelajaran dengan dengan Permainan Tradisional Engglek efektif untuk Sarana Stimulasi Perkembangan Anak Usia Dini di RA Masythoh singkir Wonosobo, model pembelajaran berupa Permainan Tradisional Engglek.
\end{abstract}

Kata kunci: Permainan Tradisional Englek, Aspek Perkembangan Anak

\begin{abstract}
This Research aims to Know Learning Model with Traditional Games Englek As Means of Stimulation Early Childhood Development, Knowing Implementation of Learning Model with Traditional Game Engglek As Means of Stimulation of Early Childhood Development. Knowing the Learning Model with Traditional Games Engglek As Means of Stimulation Early Childhood Development. The type of research is Research Development (Research and Development). The subject of the study was a group B in RA Masythoh singkir Wonosobo. Methods of data collection research using: Observation, Interview and Documentation. The results showed: (1) learning model hopscotch game is delivered with the story with the help of posters, singing together, questions and answers, guessing pictures and play puzzle theme of various professions. (2) Implementation of Learning Model of Kpk Game which can stimulate the development aspect of group B Children in RA Masythoh Singkir Wonosobo conducted twice as many meetings accordance with RKH, the average score of indicators of child development aspect increased. The results of each average of each indicator has increased aspects of child development. (3) The effectiveness of the learning model uses effective effective games. This is supported by the results of t test calculations. He conclusion of this research is the learning model with the Traditional Engglek Games effective for the Early Childhood Stimulation Facility in RA Masythoh singkir Wonosobo, the learning model of Traditional Engglek Game.
\end{abstract}

Keywords: Traditional Games Englek, Aspects of Child Development

@ Jurnal Obesi Prodi PG-PAUD FIK UPTT 2017

$\triangle$ Corresponding author :

Address : Wonosobo Jawa Tengah, Indonesia

ISSN 2356-1327 (Media Cetak)

Email: : ida_munajah@yahoo.com

ISSN 2549-8959 (Media Online) 


\section{PENDAHULUAN}

Anak adalah anugerah yang diberikan oleh Allah SWT, dimana anak dibekali dengan berbagai potensi yang dapat dikembangkan melalui pendidikan. Pendidikan anak usia dini adalah suatu pendidikan yang ditujukan kepada anak usia dini yang ditujukan untuk merangsang setiap perkembangan dan pertumbuhan anak untuk persiapan memasuki pendidikan lebih lanjut. Seperti yang dijelaskan dalam Undang-undang Sisdiknas Nomor 20 Tahun 2003 Peraturan Pemerintah tentang Pendidikan Anak Usia Dini pasal 1 ayat 1 , dinyatakan bahwa : "Pendidikan anak usia dini yang selanjutnya disebut PAUD adalah suatu upaya pembinaan yang ditunjukkan kepada anak sejak lahir sampai berusia enam tahun yang dilakukan melalui pemberian rangsangan pendidikan untuk membantu pertumbuhan dan perkembangan jasmani dan rohani agar anak memiliki kesiapan dalam memasuki pendidikan lebih lanjut".

Pendidikan pada anak usia dini lebih menitikberatkan pada peletakan dasar pertumbuhan dan perkembangan anak. Dalam proses pembelajarannya guru adalah sebagai fasilatator dan motivator untuk menggali segala potensi yang dimiliki oleh anak. Guru sebagai jembatan untuk membuat anak siap memasuki pendidikan lebih lanjut dari segi akademik, nilai agama dan norma agama serta pembiasaan perilaku yang baik. Salah satu rangsangan pendidikan untuk menyiapkan akademik, nilai agama dan norma agama serta pembiasaan perilaku yang baik dapat dilakukan melalui kegiatan bermain. Bermain merupakan salah satu aktivitas yang dapat membantu anak kearah perkembangan yang lebih baik. Hal tersebut sependapat dengan Cowel dan Hazelton dalam Sukintaka (1998:9) yang menyatakan bahwa melalui bermain akan terjadi perubahan yang positif dalam hal jasmani,sosial, mental, dan moral.

Bermain akan bermakna bagi anak usia dini dengan melalui permainan. Permainan untuk anak usia dini ini adalah permainan yang dapat merangsang kreativitas dan menyenangkan bagi anak. Permainan yang diberikan kepada anak tidak harus yang mahal, yang penting aman dan berkualitas dengan mempertimbangkan usia anak, minat, kreativitas dan keamanan. Kenyataan menunjukkan banyak orang tua beranggapan bahwa permainan yang berkualitas adalah jenis-jenis permainan dari bahan-bahan yang mahal, dan orang tua akan bangga bila bisa membelikan permainan bagi anaknya dari luar negeri (permainan import). Permainan yang aman dan berkualitas salah satunya adalah permainan tradisional. Permainan tradisional anak sudah cukup lama berkembang, permainan tersebut sarat dengan nilai-nilai budaya bangsa. Namun demikian seiring dengan perkembangan jaman permainan tradisional ini semakin lama semakin dilupakan oleh anak-anak terutama di perkotaan karena sudah semakin banyaknya permainan modern yang berasal dari luar negeri. Salah satu penyebab semakin surutnya permainan anak-anak tradisional dari tengah kehidupan anak-anak adalah adanya pesawat televisi, game online dan video game. Dengan berbagai tayangan acara yang menarik dan tidak membutuhkan tenaga untuk menikmatinya, tontonan dari pesawat televisi secara langsung menjadi hal yang lebih disukai oleh anak-anak ketimbang berbagai permainan anak-anak. Permainan tradisional menurut Yunus umumnya bersifat rekreatif, karena banyak memerlukan kreasi anak. ( Ahmad Yunus, 1981:28). Permainan ini biasanya merekonstruksi berbagai kegiatan sosial 
dalam masyarakat. Nourovita (2013:1) menyatakan bahwa "Hasil pembelajaran menunjukkan bahwa permainan tradisional jawa efektif dalam meningkatkan penyesuaian sosial anak. Hal tersebut disebabkan karena dalam permainan tradisional Jawa, anak dimungkinkan lebih banyak bermain secara kelompok dan sering berinteraksi dengan teman sebaya serta guru yang memberikan arahan sehingga anak lebih cepat akrab dan dapat bekerja sama dengan teman sebayanya. Selain itu juga anak-anak lebih menyukai kegiatan yang berbentuk permainan sehingga anak dalam mengikuti kegiatan yang berbentuk permainan tradisional jawa merasa senang, tidak jenuh dan tidak bosan."

Peran guru dan orang tua sangat penting dalam merangsang dan memfasilitasi seluruh aspek perkembangan tersebut. Berdasarkan kenyataan yang terjadi di lapangan guru anak usia dini dalam mengembangkan seluruh aspek pengembangan tersebut tidak sesuai dengan tahapan usia anak, sehingga anak merasa jenuh, bosan dan mengabaikan pembelajaran karena metode yang digunakan kurang menarik anak. Terdapat sebagian anak belum mengenal angka, bentuk, menyebutkan nama benda belum lancar, keseimbangan tubuh masih kurang dan tidak sabar menunggu antrian dalam kegiatan pembelajaran. Salah satu permainan yang dapat digunakan guru untuk mengembangkan seluruh aspek perkembangan tersebut adalah permainan tradisional Engglek yang telah banyak dilupakan oleh anak-anak, anak-anak lebih suka bermain permainan modern. Permainan Engglek merupakan salah satu jenis permainan tradisional yang menggunakan benda dan hitungan serta adanya kesepakatan peraturan-peraturan yang harus dipatuhi oleh pemain berkaitan dengan pelaksanaannya. Permainan Engglek tersebut dapat mengembangkan kemampuan kognitif dan kedisiplinan. Aspek perkembangan yang harus dikembangkan pada anak usia dini dapat menggunakan permainan tradisional Engglek . Pada permainan Engglek ini guru menyediakan gambar sesuai dengan tema yang telah direncanakan dan menambah kegiatan menyanyi, meniru gerak dan lain-lain sesuai dengan indikatornya. Gambar yang digunakan pada setiap kotak sesuai dengan tema yang direncanakan dan kegiatan dalam bentuk menyanyi, menyebut nama benda, meniru gerak, berhitung dan mengenal bentuk sesuai dengan gambar yang ditunjukkan oleh guru. Terlihat jelas bahwa permainan Engglek ini dapat mengembangkan seluruh perkembangan anak usia dini. Pengembangan model pembelajaran dengan Permainan tradisional Engglek dapat digunakan oleh guru RA sebagai sarana stimulasi dalam mengembangkan seluruh aspek perkembangan anak.

\section{METODE PENELITIAN}

Jenis penelitian ini ditinjau dari segi metode penelitian dapat dibedakan menjadi: penelitian survey, expost facto, eksperimen, naturalistic, policy, research, evaluation research, action research, sejarah, dan research and development.( Sugiyono,2008:6).

Penelitian ini termasuk dalam jenis penelitian dan pengembangan. Penelitian dan pengembangan dalam menguji suatu produk. Produk yang dimaksud dalam penelitian ini berupa model permainan tradisional engklek yang menggunakan media poster yang didesain ada gambar sesuai tema pembelajaran. Penelitian dan pengembangan berupaya menghasilkan suatu komponen dalam sistem pendidikan. 
Melalui

pengembangan dan validasi.(Samsudi, 2009:11). Modifikasi model pengembangan yang disebut oleh Thiagarajan dengan model 4D (four $D$ model), meliputi tahap pendefinisian (define), perancangan (design), dan hanya sampai tahap pengembangan (develop).( Thiagarajan, 1974:5)

Rancangan penelitian digambarkan jelas pada gambar 1.prosedur rancangan penelitian dibawah ini:

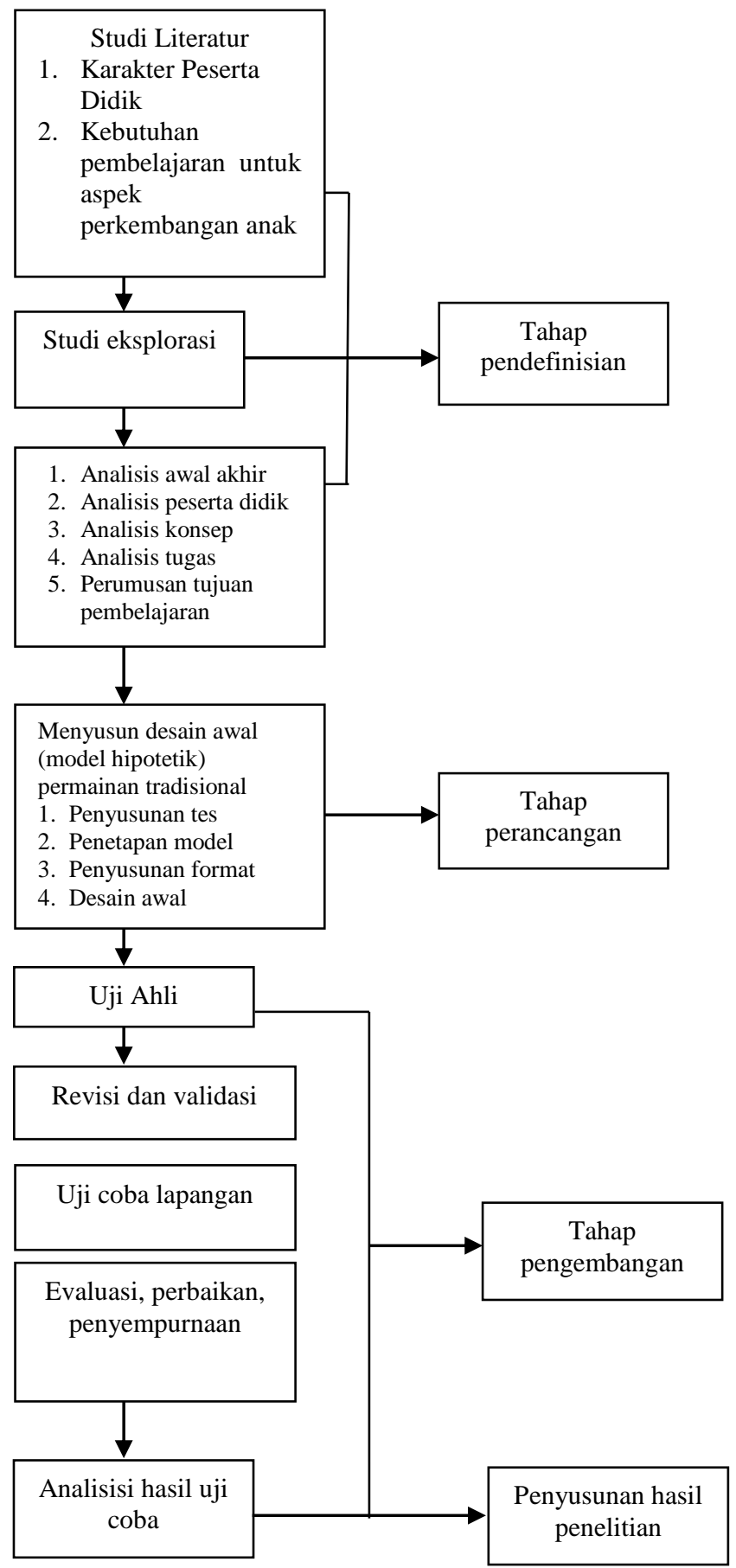

Penelitian ini menggunakan pendekatan metode penelitian dan pengembangan (research and development), yaitu metode penelitian yang digunakan untuk menghasilkan produk tertentu, dan menguji keefektifan produk tersebut, sehingga untuk dapat menghasilkan produk tertentu digunakan penelitian yang bersifat analisis kebutuhan dan untuk menguji keefektifan produk tersebut supaya dapat berfungsi dimasyarakat luas, maka diperlukan penelitian untuk menguji keefektifan produk tersebut. Jadi penelitian dan pengembangan sifatnya bertahap. Sugiyono, 2008:407)

Karakteristik subjek uji coba perlu diidentifikasi secara jelas. Populasi dan sampel yang akan digunakan sebagai subjek uji coba. Populasi adalah sebuah kelompok yang kepada mereka hasil-hasil sebuah penelitian yang dilakukan hendak digeneralisasikan.( Purwanto , 2013:86). Anggota populasi bisa berupa orang, benda, ataupun peristiwa.Istilah sampel adalah suatu kelompok yang dapat memberikan informasi atau disebut sebagai responden, yang nantinya akan digeneralisasikan dengan kelompok yang lebih besar. Subjek uji coba produk pada kelompok B yang berjumlah 15 anak di RA MAsythoh Singkir Wonosobo.

Teknik pengumpulan data merupakan langkah yang paling strategis dalam penelitian, karena tujuan utama penelitian adalah mendapatkan data. Tanpa mengetahui teknik pengumpulan dta maka, peneliti tidak akan mendapatkan data yang memenuhi standar yang ditetapkan.(Sugiyono, 2010:224)

\section{Wawancara}

Melalui wawancara dengan guru untuk mengetahui hal-hal yang lebih mendalam tentang kesulitan-kesulitan dalam penyampaian materi pembelajaran

\section{1) Observasi}

Pengumpulan data padasaat observasi diperoleh melalui pengamatan yang dilakukan oleh peneliti dan guru dengan menggunakan isntrumen lembar observasi model checklist 
2) Dokumentasi

Dokumen merupakan catatan peristiwa. Dokumen ini bisa berbentuk tulisan, foto, rekaman audio maupun video. Hasil penelitian lebih kredibel bila didukung oleh rekaman dokumentasi tersebut.

Dalam penelitian ini, metode analisis data yang diambil untuk mengetahui bagaimana kecakapan sosial anak menggunakan permainan TradisionAL engklek menggunakan analisis deskriptif dan kefektifan.

Uji coba terhadap efektifitas data kualitatif dianalisis dengan teknik analisis deskriptif naratif dan digunakan untuk memperkuat penelitian. Data kuantitatif diperoleh dari hasil pre test dan post test. Data tersebut dianalisis dengan menggunakan analisis uji perbedaan dua rata-rata menggunakan SPSS versi 16.

\section{HASIL DAN PEMBAHASAN}

Hasil penelitian yang diuraikan berupa; (1) Deskripsi tentang Pengembangan Model Pembelajaran Permainan Tradisional Engklek; (2) Pelaksanaan Model Pembelajaran Permainan Tradisional Engklek yang dapat Mengembangan aspek perkembangan Anak; (3) Analisis uji lapangan

Deskripsi tentang Pengembangan Model Pembelajaran Permainan Tradisional Engkle

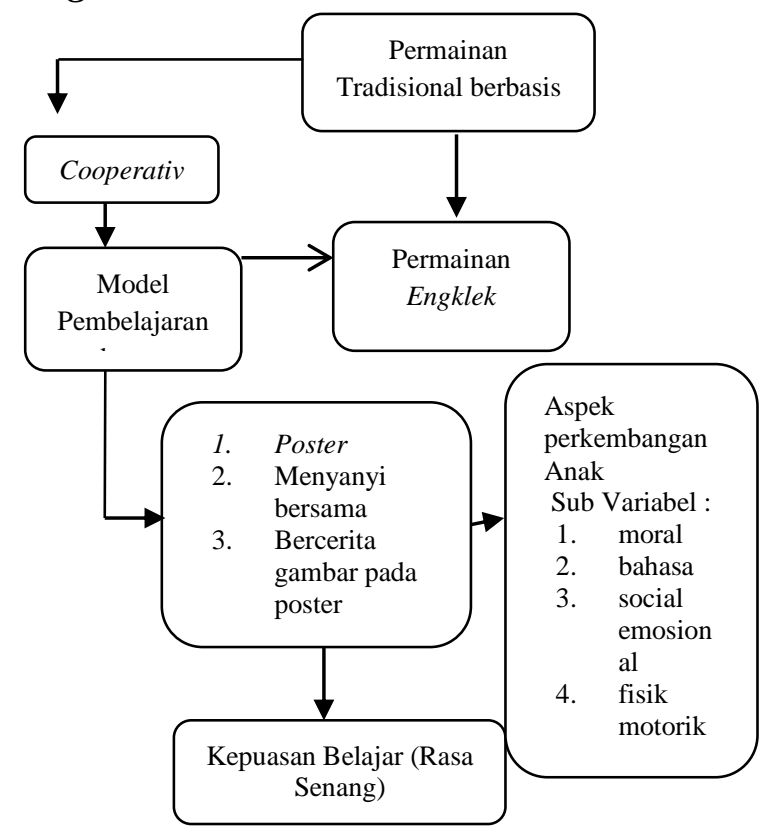

Model pembelajaran yang diterapkan di RA Masythoh Singkir Wonosobo menggunakan pembelajaran yang bersifat klasikal, anak mengerjakan lembar kerja dan majalah, guru tidak sering menggunakan nyanyian dalam pembelajaran, guru menggunakan metode ceramah anak tidak diberi kebebasan dalam bereksplorasi, beberapa anak sudah mengenal permainan Engklek diperoleh dari teman bermain dilingkungan rumahnya tanpa ada pengenalan dari orangtuanya, hanya sebatas bergabung bermain dengan anak yang lebih dewasa.

Permainan Engklek ini merupakan permainan tradisional berbasis budaya, permainan ini dijadikan model pembelajaran dengan permainan untuk anak usia dini karena termasuk permainan kooperatif yang melibatkan banyak anak, diantarkan dengan adanya cerita dari guru tentang sub tema profesi, anak melakukan kegiatan bermain engklek serta bermain puzzle yang sudag di desain yang disesuaikan dengan tema profesi. model pembelajaran dengan permainan engklek yang dilakukan oleh guru dengan bantuan poster untuk mengembangkan imajinasi visual anak. Model pembelajaran menggunakan permainan engklek memiliki tujuan yang dapat mengembangan aspek perkembangan anak yaitu aspek nilai moral, bahasa, social emosional, dan aspek fisik motorik anak.adapun penjelasannya sebagai berikut:

Mengembangkan aspek nilai moral, dalam proses belajar dengan permainan tradisional engklek ini anak membuat aturan bermain yang harus disepakati dengan teman sebayanya, anak sebelum melakukan permainan membaca do'a terlebih dahulu, anak bersikap toleran anak meliputi sabar dalam bermain, dapat memaafkan teman, menerima kesepakatan atau aturan dalam bermain, menghargai teman.

Mengembangkan aspek social emosional, meliputi semangat dalam bermain, mengikuti permainan sampai selesai, berusaha untuk tidak menjadi yang kalah. Aspek kerjasama meliputi membantu teman yang mengalami 
kesulitan, membereskan alat permainan, kompak dalam bermain. Aspek interaksi komunikasi meliputi menyapa teman, anak berani mengajukan pertanyaan, anak menjawab pertanyaan.

Mengembangan aspek bahasa, pembelajaran dengan permainan tradisional engklek ini anak menyebutkan dari masing-masing gambar profesi yang ada pada media poster, anak menyanyi bersama sesuai dengan puzzle yang dikerjakan anak setelah melakukan permainan engklek. Dengan adanya nyanyian dan menyebutkan gambar profesi yang ada pada media aspek perkembangan bahasa anak mengalami kemajuan serta anak senang melakukannya.

Mengembangkan aspek kognitif, pembelajaran dengan permainan tradisional engklek ini anak dapat mengetahui dan menyebutkan berbagai macam profesi dan tugas-tugasnya sesuai dengan media engklek yang sudah didesain ada gambarnya, serta dapat melakukan permainan yang sesuia dengan petunjuk guru.

Mengembangkan aspek seni, pembelajaran dengan permainan tradisional engklek ini anak dapat mengembangkan imajinasi dan kreativitasnya dengan cara melakukan permainan puzzle yang sudah disediakan oleh guru. dan mengembangkan aspek fisik motorik, dimana dengan permainan tradisional engklek ini anak dapat bergerak baik motorik kasar maupun halus, anak melakukan gerakan dengan mengangkat kaki satu lalu berjalan, hal tersebut dapat juga melatih keseimbangan anak dan fisik . Model pengembangan pembelajaran permainan engklek adalah salah satu cara untuk mewujudkan proses belajar menjadi lebih menyenangkan. Perbedaan model pembelajaran permainan engklek hasil pengembangan dengan model permainan engklek sebelumnya terletak pada cerita yang disampaikan guru berkaitan dengan tema profesi, sebagai pengantar anak sebelum melakukan permainan engklek yang merupakan visualisai dari permaianan engklek yang gambarkan pada poster.
Pengembangan

model pembelajaran permainan engklek dengan berbantuan poster merupakan salah satu model pembelajaran yang dapat menstimulasi aspek perkembangan anak, adanya tanya jawab, menebak pada poster serta adanya evaluasi berupa pengamatan, bernyanyi bersama serta bermain puzzle tema profesi. Pengembangan ini dilakukan oleh peneliti karena model pembelajaran aspek perkembangan anak usia dini diwilayah di RA Masythoh Singkir Wonosobo masih berpusat pada lembar kerja, tugas mengerjakan majalah dan masih terpusat pada guru serta bermain sambil belajar masih kurang sekali, pengenalan budaya terutama budaya jawa baik dalam bentuk permaianan maupun lagu jawa masih kurang, karena anak cenderung lebih mengenal gatged dibanding dengan permainan tradisional, gurupun juga tidak menerapkannya. Model pembelajaran yang diterapkan di RA MAsythoh Singkir Wonosobo masih dirasa kurang cukup untuk melatih peserta didik dalam mengeksplorasi kemampuan kognitif, bahasa, social emosional, fisik motorik, seni. yang dilakukan bermain sambil belajar yang bersifat inovatif, aktif, kreatif dan menyenangkan.

Perbedaaan model pembelajaran permainan engklek yang belum dikembangkan dan yang sudah dikembangkan bisa dilihat pada matrik di bawah ini:

\begin{tabular}{|c|c|}
\hline $\begin{array}{c}\text { Permainan asli } \\
\text { engklek }\end{array}$ & $\begin{array}{c}\text { Permainan yang } \\
\text { dikembangkan dalam } \\
\text { pembelajaran }\end{array}$ \\
\hline $\begin{array}{c}\text { Tidak ada kisah } \\
\text { pada poster }\end{array}$ & $\begin{array}{c}\text { Ada pengantar cerita } \\
\text { yang disampaikan } \\
\text { guru tentang tema } \\
\text { profesi pada poster }\end{array}$ \\
\hline Tidak ada cerita & $\begin{array}{c}\text { Diantarkan dengan } \\
\text { cerita pada poster }\end{array}$ \\
\hline $\begin{array}{c}\text { Tidak ada } \\
\text { pendampingan } \\
\text { guru/ teman } \\
\text { bermain }\end{array}$ & $\begin{array}{c}\text { Pendampingan guru } \\
\text { Tidak ada game } \\
\text { pada poster }\end{array}$ \\
$\begin{array}{c}\text { Ada game pada } \\
\text { poster, bermain } \\
\text { puzzle }\end{array}$ \\
\hline
\end{tabular}




\begin{tabular}{|c|c|}
\hline $\begin{array}{c}\text { Permainan asli } \\
\text { engklek }\end{array}$ & $\begin{array}{c}\text { Permainan yang } \\
\text { dikembangkan dalam } \\
\text { pembelajaran }\end{array}$ \\
\hline $\begin{array}{c}\text { Tidak ada } \\
\text { menyanyi }\end{array}$ & $\begin{array}{c}\text { Belajar menyanyi } \\
\text { lagu dolanan, ada } \\
\text { lagu berkaitan } \\
\text { gambar pada poster }\end{array}$ \\
\hline $\begin{array}{c}\text { Tidak ada buku- } \\
\text { buku panduan }\end{array}$ & $\begin{array}{c}\text { Ada buku-buku } \\
\text { panduan }\end{array}$ \\
\hline $\begin{array}{c}\text { Tidak ada evaluasi } \\
\text { Adab evaluasi berupa } \\
\text { observasi }\end{array}$ \\
\hline 4.1 Matrik Perbedaan Model Pembelajaran \\
Engklek
\end{tabular}

\begin{tabular}{l} 
Pelaksanaan Model Pembelajaran \\
Permainan Tradisional Engklek \\
sebagai sarana stimulasi r aspek \\
perkembangan anak usia dini di RA \\
Masythoh Singkir Wonosobo \\
\multicolumn{2}{c}{ Hasil Pelaksanaan }
\end{tabular}

Pembelajaran dengan Permainan tradisional engklek yang dapat menstimulasi aspek perkembangan anak usia dini di RA MAsythoh Singkir Wonosobo dilakukan sebanyak dua kali pertemuan, setiap pertemuan ada empat macam kegiatan yang dilakukan yaitu kegiatan awal terdiri dari: Anak diajak berbaris, mengucapkan salam, berdo'a, menyanyikan lagu dolanan . Guru menyampaikan materi pelajaran tema macam-macam profesi, guru melakukan apersepsi dengan mengajukan pertanyaan Anak-anak bisakah kalian menyebutkan salah satu macam profesi?, guru dan anak melakukan percakapan tentang salah satu macam profesi. Kegiatan inti guru menjelaskan langkah-langkah permainan tradisional engklek meliputi guru membuat aturan bermain permainan tradisional engklek, anak diminta membuat lingkaran dan semua anak melakukan teknik hompipah mencari urutan anak yang melakukan permainan engklek terlebih dahulu, Jika pada awal hompimpah disepakati, bahwa pemenang adalah telapak tangan terbuka, maka perserta yang telapak tangannya tertutup dinyatakan si kalah. Hompimpah bisa dilakukan berkalikali sampai tiap peserta mendapatkan urutan giliran bermain, Pemain nomor urut pertama memulai permainan dengan melemparkan patah ke kotak 1 .

Jika lemparannya meleset, maka ia tidak dapat meneruskan permainan, menunggu nomor urut terakhir menyelesaikan permainan. Jika berhasil, maka dia meloncat dengan satu kaki ke kotak 2, kemudian ke kotak 3 Pada kotak yang berpasangan dia boleh menjejakkan kedua kakinya. Dia terus meloncat-loncat dengan satu kaki sampai lingkaran dimana dia boleh menjejakkan kedua kakinya. Dari lingkaran, dia memutar badan, kemudian meloncat-loncat kembali seperti sebelumnya.

Pada kotak 2 dia memungut patah, loncat ke kotak 1 dan terus keluar. Selanjutnya dia melemparkan patah ke kotak 2, kemudian meloncat-loncat kembali ke kotak-kotak yang kosong (tidak ada patah). Kotak dimana ada patah tidak boleh diinjak. Dengan demikian, bisa terjadi seorang pemain harus melompat dengan melewati dua atau tiga kotak. Ketika melompat, jejakan kaki pun tidak boleh menyentuh garis karena jika melakukannya, maka dia dianggap gugur, dan harus menunggu giliran main. Melempar patah dan melompat dengan satu kaki terus dilakukan hingga lingkaran. Dari sana kemudian berputar, pemain melempar patah ke kotak-kotak yang teratas sampai yang terbawah. Pada kotak yang berpasangan, lemparan harus ditujukan ke kotak sebelah kanan terlebih dahulu, ketika anak sambil melakukan permainan engklek anak menyebutkan gambar profesi yang ada pada media poster engklek tersebut, setelah selesai melakukan kegiatan anak bermain menyusun puzzle profesi yang sduah disediakan guru. anak disuruh bertanya dan menjawab dari poster yang sudah dijelaskan guru dengan cara didampingi guru,guru memberikan pujian pada anak yang dapat menjawab dan berani bertanya . setelah itu anak Istirahat terdiri dari kegiatan mencuci tangan, berdo'a sebelum dan sesudah makan, makan bekal. Kegiatan akhir terdiri dari: guru dan anak mengulas tentang kegiatan yang dilakukan, memberi pujian sebagai bentuk motivasi pada siswa yang aktif dalam kegiatan pembelajaran, guru menyampaikan pesan, 
anak berdoa pulang dan mengucapkan salam.

Pada pertemuan kedua dilakukan hal yang sama sesuai dengan langkah diatas. Dampak dari pengembangan model pembelajaran permainan tradisional engklek di RA Masythoh Singkir Wonosobo Anakanak merasa senang dengan adanya permainan tersebut yang divisualisasikan melalui poster dan bermain puzzle yang membuat anak menarik dan anak-anak senang sekali saat disuruh maju satu persatu menabak gambar profesi yang ada pada poster yang sudah di desain, anak-anak merasa antusias dan semangat bahkan mereka minta maju lagi. Pada pertemua pertama kendalanya anak-anak masih ada yang kesusahan melafalkan lagu dolanan dan beberapa anak ada yang kurang dalam keseimbangan fisik.

Permainan tradisional engklek, dengan apresiasi siswa yang tertuang dalam sikap gembira sehingga membawa dampak bahwa aspek perkembangan anak di RA MAsythoh Singkir Wonosobo membawa dampak positif pada anak hal ini ditunjukkan dengan adanya skor rata-rata siswa pretest dan postest adanya peningkatan dari masing-masing indikator aspek perkembangan anak. untuk mencari rerata menggunakan bantuan SPSS. 16 for Windows. Hasil output perhitungan rerata masing-masing indikator dapat dilihat pada tabel 4.1

Tabel 4.1 Tabel Hasil Analisis Deskriptif Model Pembelajaran Permainan Engklek

\begin{tabular}{|c|c|c|c|c|c|c|c|c|}
\hline \multirow[t]{3}{*}{ Aspek } & \multicolumn{8}{|c|}{ Aspek perkembangan Anak } \\
\hline & \multicolumn{4}{|c|}{ Pretest } & \multicolumn{4}{|c|}{ Postest } \\
\hline & $* 1$ & $* 2$ & $* 3$ & $* 4$ & $* 1$ & $* 2$ & $* 3$ & $* 4$ \\
\hline Mean & 2,51 & 2,49 & 2,55 & 2,64 & 2,87 & 2,88 & 2,85 & 2,91 \\
\hline Std Dev & 0,86 & 0,88 & 4,21 & 0,88 & 0,92 & 0,83 & 0,81 & 0,81 \\
\hline Varians & 0,50 & 0,8 & 0,71 & 0,78 & 0,85 & 0,70 & 0,68 & 0,66 \\
\hline $\begin{array}{l}\text { Kriteria: } \\
\text { SKB(Sa } \\
\text { KB(Kur } \\
* 1=\mathrm{As} \\
* 2=\mathrm{As} \\
* 3=\mathrm{As} \\
* 4=\mathrm{As}\end{array}$ & $\begin{array}{l}\text { ang B } \\
\quad= \\
\text { mora } \\
\text { sa } \\
1 \text { emo } \\
\text { moto }\end{array}$ & $\begin{array}{l}1-1,75 \\
2,51\end{array}$ & $\begin{array}{l}=2,5 \\
\text { at Bai }\end{array}$ & 4,03 & & & & \\
\hline
\end{tabular}

Tabel 4.1 menjelaskan hasil rata-rata skor indikataor aspek perkembangan anak mengalami peningkatan hal ini dapat dilihat dari hasil pretest dan postest. menunjukan bahwa rata-rata aspek nilai moral agama 2,51(kurang baik) menjadi 2,87 (baik), aspek bahasa skor rata-rata diperoleh 2,49(kurang baik) menjadi 2,88(baik), aspek social emosional skor rata-rata diperoleh 2,55(baik) menjadi 2,85(baik), aspek fisik motorik diperoleh skor rata-rata 2,64(baik) menjadi 2,91(baik) . hasil masing-masing rata-rata dari setiap indicator mengalami peningkatan aspek perkembangan anak.

\section{Analisis Uji Ahli terhadap Model Pembelajaran melalui Permainan tradisional Engklek}

Produk awal yang dikembangkan yaitu model Pembelajaran melalui permainan tradisional engklek untuk menstimulasi aspek perkembangan anak sebelum diujicobakan perlu dilakukan validasi oleh para ahli yang sesuai dengan bidang penelitian, untuk memvalidasi produk yang dihasilkan. Validasi dilakukan dengan cara memberikan draft awal produk model pembelajaran melalui permainan tradisional engklek dengan disertai lembar evaluasi untuk ahli. Lembar evaluasi berupa kuesioner yang berisi aspek penilaian, saran, dan komentar dari para ahli terhadap model pembelajaran yakni model permainan engklek. Masukan dari ahli berkaitan dengan langkah-langkah pelaksanaan model berupa menambahkan syair lagu dolanan, urutan dalam permainan yang ada pada poster untuk diperjelas lagi dan menambah poster sehingga anak dapat mempunyai kesempatan untuk malakukan game yang ada pada poster.

Produk model pembelajaran melalui permainan tradisional engklek yang dikembangkan ini, telah mendapatkan masukan perbaikan dari beberapa ahli atau pakar, sehingga produk yang dikembangkan dapat lebih berkualitas dan mencapai tujuan 
pengembangan model yang diharapkan. Selengkapnya, terkait hasil penilaian model yang diperoleh dari pakar atau ahli dapat dilihat pada lampiran.

Data yang tersaji merupakan hasil penilaian pakar dan ahli terhadap produk model pembelajaran melalui permainan tradisional engklek yang telah dikembangkan. Penilaian ini disajikan agar dapat dilihat sejauh mana kualitas produk yang telah dikembangkan.

Model pembelajaran melalui permainan tradisional engklek yang dikembangkan masih terdapat kekurangan. Hal ini diketahui setelah dilakukan proses penilaian oleh pakar atau ahli. Namun saran yang disampaikan oleh pakar atau ahli terhitung sedikit. Revisi tidak sampai merubah sintaks model. Lebih lanjut, saran yang ada lebih cenderung pada kelengkapan yang mendukung pengembagan model tersebut.

\section{Hasil Analisis Uji Coba Produk Model Pembelajaran melalui Permainan tradisional engklek}

Bagian ini merupakan analisis data yang terdiri atas: (1) Deskripsi Data Hasil Uji Coba; (2) Uji Keefektifan Produk. Penelitian ini merupakan penelitian pengembangan yang meliputi beberapa tahapan sebagaimana yang sudah dijelaskan pada bab 3. Tahap selanjutnya, hasil pengembagan model pembelajaran melalui permainan tradisional engklek dinilai oleh pakar atau ahli untuk memperoleh masukan terhadap model yang dikembangkan. Hasil penilaian tersebut kemudian direvisi sesuai dengan masukan dan perbaikan dari pakar dan dilakukan proses perbaikan produk yang dikembangkan, melakukan uji lapangan di RA Masythoh Singkir Wonosobo.

\section{Hasil Analisis Deskriptif Aspek Perkembangan Anak}

Analisis deskriptif bertujuan untuk mengetahui sejauh mana tingkat perkembangan hasil belajar siswa sebelum dan setelah mengikuti proses pembelajaran. Data diolah menggunakan bantuan SPSS. 16 for Windows, untuk melihat hasil belajar siswa sebelum dan setelah menggunakan model pembelajaran melalui permainan tradisional engklek. Data yang dideskripsikan antara lain hasil pretest dan posttest pada kelompok uji coba. Dari perhitungan analisis deskriptif diperoleh hasil skor rata-rata yang diperoleh menunjukan bahwa rata-rata aspek nilai moral agama 2,51(kurang baik) menjadi 2,87 (baik), aspek bahasa skor rata-rata diperoleh 2,49(kurang baik) menjadi 2,88 (baik), aspek social emosional skor ratarata diperoleh 2,55(baik) menjadi 2,85(baik), aspek fisik motorik diperoleh skor rata-rata 2,64(baik) menjadi 2,91(baik) . hasil masingmasing rata-rata dari setiap indicator mengalami peningkatan aspek perkembangan anak.

Hal ini terbukti bahwa aspek perkembangan anak setelah menggunakan permainan tradisional engklek lebih tinggi dibanding dengan sebelum adanya pengembangan model.

Pembelajaran melalui permainan tradisional engklek merupakan pembelajaran inovatif, kreatif, aktif dan menyenangkan, yang mengangkat nilai budaya berupa permainan tradisional engklek. Guru perlu memiliki kreativitas dalam mengembangkan permainan sebagai pendekatan dalam pembelajaran anak usia dini. Permainan ini diperlukan media berupa poster untuk mengembangkan imajinasi visual anak dan membantu guru bercerita secara sistematis. Poster ini memiliki tempat-tempat yang ada gambar sesuai tema profesi.

Nilai-nilai seni budaya yang ditanamkan adalah dalam bentuk lagu dolanan yang menggunakan bahasa jawa. Pengembangan model pembelajaran melalui permaianan tradisional engklek ini dilaksanakan dalam enam langkah yang akan digambarkan pada gambar di bawah ini:

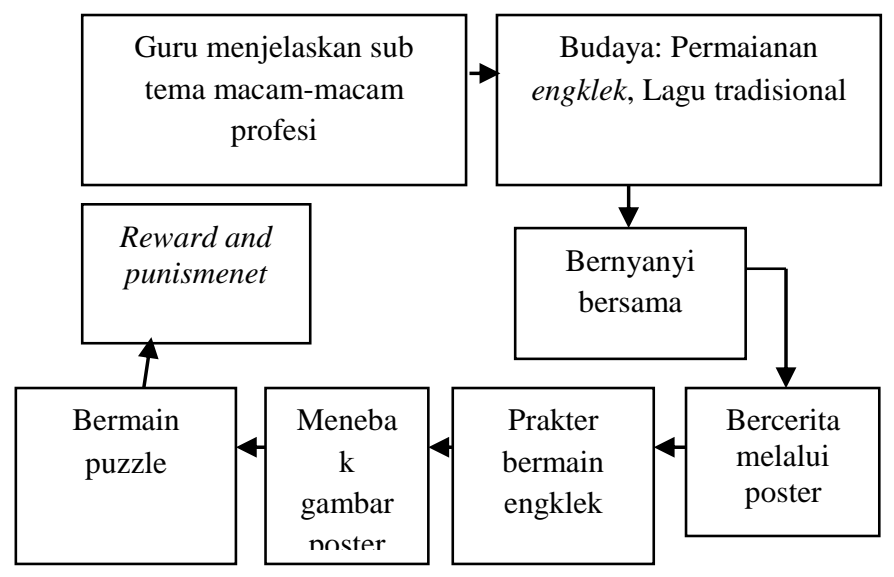

Gambar 4.2 Langkah Pembelajaran melalui Permaianan tradisional engklek 
Langkah-langkah tersebut akan dijelaskan sebagai berrikut:

\section{Langkah I:}

Guru menjelaskan tema macammacam profesi dengan cara memberikan cerita ilustrasi berkaitan dengan tugas dari profesi, guru menjelaskan gambar yang ada pada media poster permainan tradisional engklek, serta mengenalkan permainan tradisional engklek sebagai khazanah budaya bangsa

Langkah II:

Guru mengajak anak menyanyikan lagu dolanan padhang bulan

Yo prakanca dolanan ing njaba.

Padhang mbulan padhange kaya rina ngélikaké rembulané kang ngawé-awé

aja turu soré-soré

Syair dari tembang dolanan padang bulan apabila diterjemahkan ke dalam bahasa Indonesia menjadi:

'Ayo teman-teman bermain di luar' benderang'

'Cahaya bulan yang terang

'Rembulan yang seakan-akan melambaikan tangan'

'Mengingatkan kepada kita untuk tidak tidur sore-sore'

langkah III:

Guru melihatkan poster media permainan tradisional engklek pada anak, dilanjutkan guru bercerita dengan berbantuan poster tersebut berkaitan dengan tema profesi
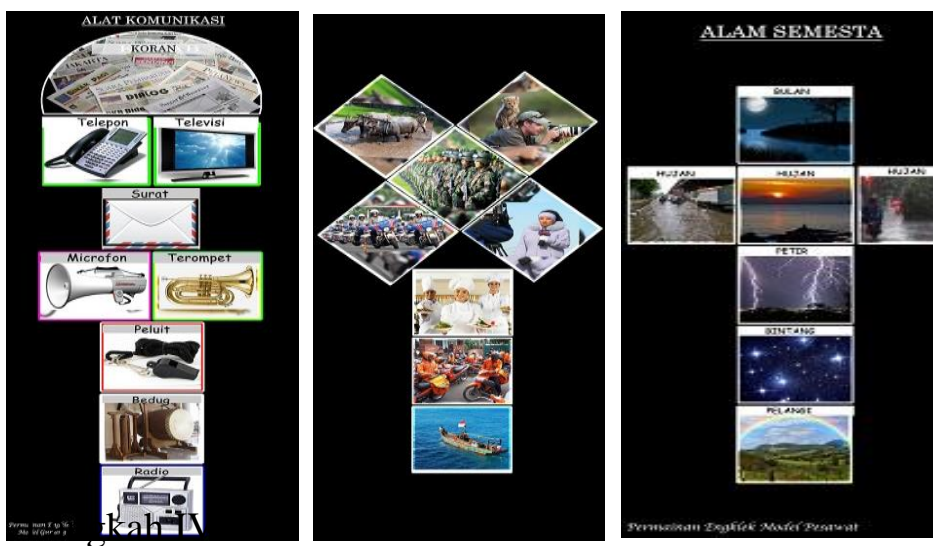

Guru mengajak siswa untuk mempraktekkan permainan Tradisional engklek yang sudah digambarkan pada poster tersebut dengan cara:

a. Guru menjelaskan urutan permainan tradisional engklek:
1) Anak diminta membuat lingkaran dengan teknik hompimpah

2) Para pemain harus melompat dengan menggunakan satu kaki di setiap kotak-kotak / petak-petak yang telah digambarkan di media poster permainan tradisional engklek sambil menyebutkan gambar profesi yang ada pada media poster engklek

3) Guru memberikan kepada setiap anak gacuk yang biasanya berupa pecahan genting / kreweng, keramik lantai, ataupun batu yang datar. Namun dalam hal ini guru memberikan tutup kepda siswa yang digunakan sebagai gacuk.

4) Kereweng/gacuk dilempar ke salah satu petak yang tergambar di poster, petak dengan gacuk yang sudah berada diatasnya tidak boleh diinjak/ditempati oleh setiap pemain, jadi para pemain harus melompat ke petak berikutnya dengan satu kaki mengelilingi petak-petak yang ada.

5) Pemain tidak diperbolehkan untuk melemparkan

kereweng/gacuk hingga melebihi kotak atau petak yang telah disediakan. Jika ada pemain yang melakukan kesalahan tersebut maka pemain tersebut akan dinyatakan gugur dan diganti dengan pemain selanjutnya.

6) Pemain yang menyelesaikan satu putaran terlebih dahulu melemparkan gacuk dengan cara membelakangi engkleknya, jika kereweng atau gacuk jatuh tepat pada salah satu petak maka petak tersebut akan menjadi daerah kekuasaan pemain. Kemudian pada petak tersebut, pemilik sawah boleh menginjak petak dengan dua kaki, sedangkan pemain lain tidak boleh menginjak petak tersebut selama permainan. Pemain yang memiliki sawah paling banyak adalah pemenangnya.

7) Setiap anak setelah selesai melakukan satu putaran permainan engklek anak bermain menyusun puzzle profesi. 
b. Permainan dimulai

c. Guru memberikan penilaian aspek perkembangan anak melalui proses pengamatan

\section{SIMPULAN}

Model pembelajaran dengan menggunakan permainan tradisional engklek ini diantarkan dengan cerita dengan bantuan poster, tanya jawab, menyanyi bersama, bermain puzzle, anak praktek memainkan permainan tradisional engklek. Pelaksanaan Model Pembelajaran Permainan tradisional engklek yang dapat menstimulasi aspek perkembangan Anak Kelompok B di RA Masythoh Singkir Wonosobo. Model pembelajaran dengan menggunakan permainan tradisional engklek untuk menstimulasi aspek perkembangan anak berbantuan poster pada anak kelompok B di RA Masythoh Andongsili Wonosobo efektif.

\section{DAFTAR PUSTAKA}

Ahmad Yunus. 1981, Permainan Rakyat Daerah Istimewa Yogyakarta. Yogyakarta: Departemen Pendidikan dan Kebudayaan.

Astuti, A. (2016). Peningkatakan Kemampuan Anak Mengenal Konsep Bilangan Melalui Permainan Kartu Angka di Kelompok B TK Aisyiyah Pulau Payung Kecamatan Rumbio Jaya.Jurnal Obsesi, 2(1), 90-99. Retrieved from http://journal.stkiptam.ac.id/ind ex.php/obsesi/article/view/169

Joni, J. (2016). Peningkatan Kemampuan Kognitif Anak dalam Kegiatan Berhitung dengan Permainan Dadu TK Mutiara Pekanbaru. Jurnal Obsesi, 2(1), 1-10

Putri Nourovita, Aulia Rifki. Efektivitas Permainan Tradisional Jawa dalam Meningkatkan Penyesuaian Sosial pada Anak Usia 4-5 tahun di Kecamatan Suruh ,(Early Childhood Education Papers ( Belia) 2. 2013) (1). http://journal.unnes.ac.id/sju/index.p $\mathrm{hp} / \mathrm{belia}$
Samsudi. 2009, desain penelitian pendidikan. semarang: UNNES Press.

Thiagarajan, s,1974. Dan Others. intructional development for teacher of exceptional children. Bloomington: indiana university,

Sugiyono , 2008, metode penelitian pendidikan kuantitatif, kualitatfi, dn $R \& D$. Bandung alfabeta,

Purwanto.. 2013, Evaluasi Hasil Belajar.Yogyakarta: Pustaka Pelajar,

Sugiyono. 2010, Metode penelitian Pendidikan, pendekatan kualitatif, kuantitatif dan $R \quad \& \quad D$. Bandung:Alfabeta 